\title{
Study of the antimicrobial and fungicidal activity of thiotriazoline and decamethoxinum as a potentially new model mixture for use of the oral mucosa
}

\author{
L. I. Kucherenko ID*1,2,F, I. F. Bielenichev (D)1,A,E, O. O. Chonka (iD 1,B,C,D, Z. B. Moriak (D) 1,F,E, O. O. Portna iD 1,E
}

'Zaporizhzhia State Medical University, Ukraine, ${ }^{2 S P A}$ “Farmatron”, Zaporizhzhia, Ukraine

A - research concept and design; B - collection and/or assembly of data; C - data analysis and interpretation; D - writing the article;

$\mathrm{E}$ - critical revision of the article; $\mathrm{F}$ - final approval of the article

Today, diseases caused by pathogenic bacteria are the most dangerous, as they can not only affect the quality of human life, but also lead to death.

According to the WHO, pathogenic bacteria namely, mycoses affect from $1 / 5$ to $1 / 3$ of the world's population, more than a third (37.8 $\%$ ) of them cause yeast-like (Candida). Over the past 20 years, there has been a 15-fold increase in the frequency of infectious inflammatory diseases of candidiasis etiology.

After examining the range of drugs on the pharmaceutical market of Ukraine and abroad, it was found that the following drugs of foreign origin are currently used for the treatment of these diseases: Methyluracil (Lekhim, Ukraine), Solkoseril (Birsfelden, Switzerland), Mexidol (PHARMASOFT, Moscow, RF).

Based on the above it is seen that the range of drugs for the treatment of oral mucosa diseases is limited. All of the above shows the need for the creation of a new domestic drug exhibiting antimicrobial, fungicidal, reparative activity.

The aim of our work is to create a new drug based on the model mixture of Thiotriazoline and Decamethoxinum, which exhibit antimicrobial, fungicidal, repertoire activity.

Materials and methods. Thiotriazoline, decamethoxinum, model mixture. The studies were carried out by agar diffusion (well method) to study antimicrobial activity. Model mixtures with decamethoxinum were made from 0.5 to $5.0 \mathrm{mg}$; thiotriazoline $-200 \mathrm{mg}$. Antimicrobial activity of these model mixtures was carried out.

Results. The model mixture of thiotriazoline and decamethoxinum in antimicrobial and fungicidal action was significantly superior to decamethoxinum by $54 \%$ in the degree of growth inhibition of S. aureus, by $120 \%$ in the degree of growth inhibition of $E$. coli, by $57 \%$ in the degree of growth inhibition of $P$. aeruginosa, and by $108 \%$ in the degree of growth retardation of $C$. albicans at $10^{6} \mathrm{CFU} / \mathrm{ml}$ of medium.

Conclusion. The model mixture of thiotriazoline and decamethoxinum exhibits high antimicrobial and fungicidal activity.

Key words: oral mucosa, pathological processes, model mixture, thiotriazoline, decamethoxinum.

Current issues in pharmacy and medicine: science and practice 2020; 13 (3), 349-353

Вивчення протимікробної та фунгіцидної активності тіотріазоліну та декаметоксину як потенційно нової модельної суміші для застосування при захворюваннях слизової оболонки порожнини рота

\section{Л. І. Кучеренко, І. Ф. Бєленічев, О. О. Чонка, З. Б. Моряк, О. О. Портна}

Захворювання, які викликають хвороботворні бактерії, - найнебезпечніші, оскільки здатні не тільки впливати на якість життя людини, але і призводити до летальних наслідків.

Згідно з даними ВООЗ, хвороботворними бактеріями, як-от мікозами, уражено від 1/5 до 1/3 населення планети, у понад третини (37,8 \%) з них збудником захворювання є дріжджоподібні гриби роду Candida. За останні 20 років фрахівці спостерігають підвищення в 15 разів частоти інфекційних запальних захворювань кандидозної етіології.

Вивчивши асортимент лікарських препаратів на фармацевтичному ринку України та за кордоном, установили: для лікування цих захворювань використовують лікарський засіб Метилурацил (Лекхім, Україна) та препарати іноземного виробництва Соркосерил (Бірсфельден, Швейцарія), Мексидол (ФАРМАСОФТ, м. Москва, РФ).

ARTICLE

INFO

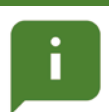

http:l/pharmed.

zsmu.edu.ualarticle/ view/216197
UDC 615.31:547.792]:615.28]].015.11:616.22-002

DOI: $10.14739 / 2409-2932.2020 .3 .216197$

Current issues in pharmacy and medicine: science and practice 2020; 13 (3), 349-353

Key words: oral mucosa, pathological processes, model mixture, thiotriazoline, decamethoxinum.

*E-mail: farm chem@bigmir.net

Received: 18.08.2020 // Revised: 02.09.2020 // Accepted: 06.09.2020 
Асортимент лікарських засобів для лікування захворювань слизової оболонки порожнини рота - обмежений. Отже, є потреба у створенні нового вітчизняного препарату, що проявлятиме антимікробну, фунгіцидну, репаративну активність.

Мета роботи - створення нового лікарського засобу на основі модельної комбінації тіотріазоліну й декаметоксину, що проявлятиме антимікробну, фунгіцидну, репаративну активність.

Матеріали та методи. Тіотріазолін, декаметоксин, модельна суміш тіотріазоліну та декаметоксину. Дослідження антимікробної активності здійснили методом дифузії в агар (метод колодязів). Виготовили модельні суміші з вмістом декаметоксину від 0,5 до 5,0 мг; тіотріазоліну - 200 мг. Перевірена антимікробна активність цих модельних сумішей.

Результати. Модельна суміш тіотріазоліну та декаметоксину за силою антимікробної та фунгіцидної дії вірогідно перевершувала декаметоксин на 54 \% за ступенем затримки росту S. aureus, на $120 \%$ - за ступенем затримки росту E. coli, на $57 \%$ - за ступенем затримки росту P. aeruginosa, на 108 \% - за ступенем затримки росту C. albicans при 106 КУО/мл середовища.

Висновки. Модельна суміш тіотріазоліну та декаметоксину має високу антимікробну, фунгіцидну, репаративну активність.

Ключові слова: захворювання слизової оболонки порожнини рота, модельна суміш, декаметоксин, тіотріазолін.

Актуальні питання фрармацевтичної і медичної науки та практики. 2020. Т. 13, № 3(34). С. 349-353

\section{Изучение противомикробной и фунгицидной активности тиотриазолина и декаметоксина как потенциально новой модельной смеси для применения при заболеваниях слизистой оболочки полости рта}

\section{Л. И. Кучеренко, И. Ф. Беленичев, Е. О. Чонка, З. Б. Моряк, Е. А. Портная}

Сегодня болезни, вызываемые болезнетворными бактериями, - самые опасные, так как они способны не только влиять на качество жизни человека, но и привести к смертельному исходу. По данным ВОЗ, болезнетворными бактериями, а именно микозами, поражено от $1 / 5$ до $1 / 3$ населения Земли, более чем у трети (37,8 \%) из них возбудителем заболевания являются дрожжеподобные грибы рода Candida. За последние 20 лет отмечено повышение в 15 раз частоты инфекционных воспалительных заболеваний кандидозной этиологии.

Изучив ассортимент лекарственных препаратов на фармацевтическом рынке Украины и за рубежом, установили: для лечения данных заболеваний используют Метилурацил (Лекхим, Украина) и препараты иностранного производства Соркосерил (Бирсфельден, Швейцария), Мексидол (ФАРМАСОФТ, г. Москва, РФ).

Ассортимент лекарственных средств для лечения заболеваний слизистой оболочки полости рта - ограничен. Следовательно, возникла необходимость создать новое отечественное лекарственное средство, проявляющее антимикробную, фуунгицидную, репаративную активность.

Цель работы - создание нового лекарственного средства на основе модельной комбинации тиотриазолина и декаметоксина, проявляющего антимикробную, фунгицидную, репаративную активность.

Материалы и методы. Тиотриазолин, декаметоксин, модельная смесь тиотриазолина и декаметоксина. Противомикробная активность исследована методом дифффузии в агар (метод колодцев). Изготовлены модельные смеси с содержанием декаметоксина от 0,5 до 5,0 мг; тиотриазолина - 200 мг. Проверена противомикробная активность данных модельных смесей.

Результаты. Модельная смесь тиотриазолина и декаметоксина по силе антимикробного и фунгицидного действия достоверно превосходила декаметоксин на 54 \% по степени задержки роста S. aureus, на $120 \%$ - по степени задержки pocта E. coli, на 57 \% - по степени задержки роста P. aeruginosa и на 108 \% - по степени задержки роста C. albicans при $10^{6}$ KOE/мл среды.

Выводы. Модельная смесь тиотриазолина и декаметоксина проявляет высокую антимикробную, фунгицидную активность.

Ключевые слова: заболевания слизистой оболочки полости рта, модельная смесь, декаметоксин, тиотриазолин.

Актуальные вопросы фрармацевтической и медицинской науки и практики. 2020. Т. 13, № 3(34). С. 349-353

Oral health is one of the main indicators of overall health, well-being, and quality of life. WHO defines oral health as "a condition characterized by the absence of chronic pain in the oral cavity and in the face, oral cancer of the mouth and throat, infections and ulcers of the oral cavity, periodontal disease (gums), dental caries, tooth loss and other diseases and disorders health, limiting a person's ability to bite, chew, smile and speak and his psychosocial well-being" [4].

Most of the burden of oral disease is attributable to seven diseases and conditions of the oral cavity. These include dental caries, periodontal (gum) diseases, oncological diseases of the oral cavity, intraoral manifestations of HIV infection, injuries of the oral cavity and teeth, cleft lip and palate, and noma. Almost all diseases and conditions are either largely preventable or treatable in the early stages [1].

The 2016 Global Burden of Disease Survey estimates that at least 3.58 billion people worldwide suffer from oral diseases, and dental caries of permanent teeth is the most common among the estimated health problems. With increasing urbanization and changing living conditions, the prevalence of oral diseases continues to increase significantly due to insufficient exposure to fluoride compounds and inadequate access to primary oral health services. Aggressive marketing of sugars, tobacco and alcohol leads to increased consumption of unhealthy foods.

Today, diseases caused by bacteria are the most dangerous, as they can not only aggravate a person's quality of life, but also lead to death. 
Despite advances in medical technologies, diseases caused by microorganisms remain relevant and are gaining increasing medical and social significance. According to foreign and domestic researchers, these pathologies join the underlying disease in 5-20\% of patients and occupy tenth place among the causes of population mortality.

Methicillin - resistant Staphylococcus aureus is of particular concern, the methicillin resistance mechanism provides it with resistance to all semisynthetic penicillin's and cephalosporins, thereby significantly complicating the patients treatment.

The prevalence of MRSA varies widely in different countries, accounting for less than $2 \%$ of all Staphylococcus aureus (S. aureus) in Switzerland and over $70 \%$ in Japan and Hong Kong. In Europe, about 200 thousand cases of MRSA infections are registered annually with $7 \%$ of deaths $[2,8]$.

According to the WHO, from $1 / 5$ to $1 / 3$ of the world's population are affected by mycoses, more than a third (37.8\%) of them cause yeast-like (Candida) mold fungi. Despite the success of the pharmaceutical industry, the introduction of new technologies, over the past 20 years there has been an increase in the frequency of infectious and inflammatory diseases of candidiasis etiology by 15 times. It should be noted that, according to the 2016 Global Disease Time Survey, at least 3.58 billion people in the world suffer from oral diseases, the most common being caused by Candida microorganisms [4].

With the development and progress of mankind, the prevalence of Candida inflammatory diseases races up. If at the beginning of the twentieth century this disease occurred in people of 40 years or older, then already in the 80-90s the disease became noticeable throughout the world. However, the used drugs, each of which acts on a specific link in the pathological process, have a number of side effects and do not always allow you to quickly stop periodontal inflammation [6].

Currently, various injuries and inflammatory processes of the oral mucosa of various etiologies are one of the common conditions of diseases.

According to the World Health Organization, the oral mucosa is $38 \%$ of all diseases, and at present, the share of this pathology is about $62 \%$. Despite numerous studies in this area, diseases of the mucous membrane of the mouth are an urgent problem of modern fundamental and clinical medicine and pharmacy $[3,5]$.

Despite the large arsenal of anti-inflammatory, antibacterial, wound healing agents, the traditional treatment of this pathology does not always give the expected result. In addition, quite often traditional therapy gives rise to complications, which complicates the treatment of a particular patient. In this regard, the development and creation of drugs that can effectively affect the main target links of inflammatory diseases of the oral mucosa is an urgent task of modern pharmacology [7].

The development of the dental service in recent years, especially in the context of market relations, has highlighted the issues of improving the quality of treatment. One of the main directions of ensuring the quality of dental care is the search for new drugs for the treatment of pathologies. Therefore, the task of creating new drugs is the most relevant in the pharmaceutical industry.

After examining the range of drugs on the pharmaceutical market of Ukraine and abroad, it was found that for the treatment of these diseases the following drugs of foreign origin are currently used: Methyluracil (Lekhim, Ukraine), Solkoseril (Birsfelden, Switzerland), Mexidol (PHARMASOFT, Moscow, RF).

Decamethoxinum is currently the most commonly used drug from the group of antiseptics, it belongs to the group of aseptic and disinfectants, and has a number of side effects, namely allergic reactions caused by a decrease in immunity.

Therefore, thiotriazoline became of particular interest as the second ingredient to create a model mixture. It has a wide range of actions, namely immunostimulating, wound healing, reparative function.

In the course of the work, the employees of the Department of Pharmaceutical Chemistry of Zaporizhzhia State Medical University (ZSMU) together with the specialists of the SPA "Farmatron" decided to use a model mixture of decamethoxinum with thiotriazoline where thiotriazoline will exhibit antioxidant effects thereby inhibiting the side effects of decamethoxinum.

\section{Aim}

Therefore, the aim of our work is to study the antimicrobial and fungicidal activity of thiotriazoline and decamethoxinum combination which will exhibit antimicrobial and fungicidal effects.

\section{Materials and methods}

Thiotriazolin (0.2), decamethoxin (0.002), model mix, petri dishes, test strains. The results of the study were calculated using the standard statistical package of the licensed program Statistica ${ }^{\circledR}$ for Windows 6.0 (StatSoft Inc., No.AXXR712D833214FAN5), as well as SPSS 16.0 and Microsoft Office Excel 2003. Distribution normality was assessed using the Shapiro-Wilk test, analysis of variance (ANOVA), and U Mann-Whitney test was used.

The study of the antimicrobial and fungicidal activity of a combination of thiotriazolin and decamethoxin was carried out by agar diffusion (well method). Staphylococcus aureus cultures (Staphylococcus aureus ATCC 25923, Escherichia coli ATCC 25922, Pseudomonas aeruginosa tuberculosis and Pseudomonas aeruginosa pseudomonas aeruginosa) were used as test strains. Fungus (thrush) - Candida albicans ATCC 885-653, from which a microbial suspension with a concentration of colony forming units (CFU) was prepared$106 \mathrm{CFU} / \mathrm{ml}$. Muler-Hinton agar was used for studies with S. aureus, E. coli, P. aeruginosa, with C. albicans - yeah Saburo. According to generally accepted methods, thinwalled cylinders with a diameter of $7 \mathrm{~mm}$ were installed in Petri dishes with pre-poured and cooled agar and $13.5 \mathrm{ml}$ of agar melted and cooled to $45^{\circ} \mathrm{C}$ mixed with a seeded dose $(1.5 \mathrm{ml})$ of the test microorganism was poured. The cylinders 
were removed and $0.3 \mathrm{ml}$ of the combination solution was added to the obtained wells. The results of studies with strains of $S$. aureus, E. coli, and P. aeruginosa were evaluated after 24 hours of incubation, in crops with $C$. albicans, first after 24 hours, then after 48 hours. The results were calculated by measuring growth inhibition zones ( $\mathrm{mm}$ ).

\section{Results}

The research has shown that the studied model mixtures exhibit antimicrobial and fungicidal activity with a decamethoxinum content of from 0.5 to $5.0 \mathrm{mg}$. The administration of thiotriazoline also have led to the potentiation of the effect of decamethoxinum. Apparently, the membrane-tropic effect lies in the mechanism of the potentiating effect, which leads to an increase in the saponifying action, namely, an increase in the bactericidal mechanism of decamethoxinum on microbes.

Further increase in the content in the combination of decamethoxinum did not lead to a significant increase in antimicrobial and antifungicidal activity.
The statistical significance between the mean values was determined by the Student's test with a normal distribution. In case of a non-normal distribution or analysis of ordinal variables, the U Mann-Whitney test was used. For comparison of independent variables in more than two samples, analysis of variance (ANOVA) with normal distribution or the Kruskal-Wallis test for a distribution other than normal were used. For all types of analysis, differences of $\mathrm{P}<0.05$ ( $95 \%$ ) were considered statistically significant. As a result of the studies, it was found that the studied combinations exhibit antimicrobial and fungicidal activity when the content of decamethoxinum is from 0.5 to $5.0 \mathrm{mg}$ (Table 1).

\section{Discussion}

As a result of the research, it was found that the studied the zones of growth inhibition ( $\mathrm{mm}$ ) of microorganisms cultures (Table 2). However, the maximum activity against the studied strains of microorganisms and thrush (C. albicans) was observed at a dose of $2 \mathrm{mg}$ of decamethoxinum, both when diluting $10^{7} \mathrm{CFU} / \mathrm{ml}$ of medium, and when diluting $10^{6} \mathrm{CFU} / \mathrm{ml}$ of medium.

Table 1. Studies of the antimicrobial and fungicidal activity of a combination of thiotriazoline $(200 \mathrm{mg})$ with different decamethoxinum contents $(0.5-5.0 \mathrm{mg})$

\begin{tabular}{|c|c|c|c|c|c|c|c|}
\hline \multirow{2}{*}{ Strains } & \multicolumn{7}{|c|}{ The diameter of the delayed growth zone $(\mathrm{mm})$ at $10^{7} \mathrm{CFU} / \mathrm{ml}$ of medium, $\mathrm{mm}$} \\
\hline & $0.5 \mathrm{mg}$ & $1 \mathrm{mg}$ & $1.5 \mathrm{mg}$ & $2 \mathrm{mg}$ & $2.5 \mathrm{mg}$ & $3 \mathrm{mg}$ & $5 \mathrm{mg}$ \\
\hline C. albicans & 19 & 19 & 20 & 24 & 24 & 24 & 24 \\
\hline S. aureus & 17 & 20 & 20 & 21 & 21 & 21 & 21 \\
\hline E. coli & 0 & 0 & 9 & 18 & 18 & 24 & 24 \\
\hline \multirow[t]{2}{*}{$P$. aeruginosa } & 0 & 0 & 12 & 13 & 13 & 14 & 14 \\
\hline & \multicolumn{7}{|c|}{ The diameter of the delayed growth zone $(\mathrm{mm})$ at $10^{6} \mathrm{CFU} / \mathrm{ml}$ of medium, $\mathrm{mm}$} \\
\hline C. albicans & 20 & 22 & 22 & 25 & 25 & 25 & 25 \\
\hline S. aureus & 16 & 16 & 25 & 25 & 25 & 25 & 25 \\
\hline E. coli & 0 & 0 & 8 & 22 & 22 & 22 & 22 \\
\hline P. aeruginosa & 10 & 10 & 16 & 16 & 16 & 16 & 16 \\
\hline
\end{tabular}

Table 2. Antimicrobial activity of the studied combination according to the size of the zones of growth inhibition $(\mathrm{mm})$ of microorganisms cultures $\left(10^{7} \mathrm{CFU} / \mathrm{ml}\right.$ of medium)

\begin{tabular}{|l|l|l|l|l|}
\hline Dosage form & S. aureus & E. coll & P. aeruginosa & C. albicans \\
\hline $\begin{array}{l}\text { 1. Thiotriazoline }(0.003 \mathrm{mg}) \\
+ \text { decamethoxinum }(0.0003 \mathrm{mg})\end{array}$ & $20.3 \pm 0.57^{*}(+42 \%)$ & $12.7 \pm 1.15^{*}(+81 \%)$ & $12.3 \pm 0.57^{*}(+60 \%)$ & $15.0 \pm 0.01^{*}(+95 \%)$ \\
\hline 2. Decamethoxinum $(0.0003 \mathrm{mg})$ & $14.3 \pm 0.57$ & $7.0 \pm 0.01$ & $7.7 \pm 0.57$ & $7.7 \pm 0.577$ \\
\hline 3. Chlorhexidine $(0.0024 \mathrm{mg})$ & $31.3 \pm 1.15^{*}(+8 \%)$ & $23.3 \pm 0.57^{*}(+232 \%)$ & $19.0 \pm 0.01^{*}(+146 \%)$ & $24.7 \pm 0.57^{*}(+220 \%)$ \\
\hline
\end{tabular}

Table 3. Antimicrobial activity of the studied combination according to the size of the zones of growth inhibition (mm) of microorganisms cultures $\left(10^{6} \mathrm{CFU} / \mathrm{ml}\right.$ of medium)

\begin{tabular}{|c|c|c|c|c|}
\hline Dosage form & S. aureus & E. coli & P. aeruginosa & C. albicans \\
\hline $\begin{array}{l}1 \text { Thiotriazoline }(0.003 \mathrm{mg}) \\
+ \text { decamethoxinum }(0.0003 \mathrm{mg})\end{array}$ & $22.7 \pm 0.57^{*}(+54 \%)$ & $16.0 \pm 0.01^{*}(+120 \%)$ & $13.0 \pm 1.0^{*}(+57 \%)$ & $16.0 \pm 0.01^{*}(+108 \%)$ \\
\hline 2. Decamethoxinum (0.0003 mg) & $14.7 \pm 0.57$ & $7.3 \pm 0.57$ & $8.3 \pm 0.57$ & $7.7 \pm 0.57$ \\
\hline 3. Chlorhexidine (0.0024 mg) & $35.0 \pm 0.01^{*}(+138 \%)$ & $26.0 \pm 0.01^{*}(+256 \%)$ & $20.0 \pm 0.01^{*}(+141 \%)$ & $25.0 \pm 0.01^{*}(+225 \%)$ \\
\hline
\end{tabular}

*: changes are significant in relation to group No. 2 (decamethoxinum) $(\mathrm{P}<0.05)$. 
Thus, it was found that the thiotriazoline and decamethoxinum combination was active against $S$. aureus, E. coli, $P$. aeruginosa and $C$. albicans (diploid yeast-like fungus (thrush)). S. aureus, E. coli, P. aeruginosa and C. albicans were the most common pathogens of inflammatory diseases of the urogenital sphere. As a result of the studies combination according to the size of the zones of growth inhibition ( $\mathrm{mm}$ ) of microorganisms' cultures (Table 3).

The model mixture with thiotriazoline and decamethoxinum in antimicrobial and fungicidal strength significantly exceeded decamethoxinum by $54 \%$ in the degree of growth inhibition of $S$. aureus, by $120 \%$ in the degree of growth inhibition of $E$. coli, by $57 \%$ in the degree of growth inhibition of $P$. aeruginosa and by $108 \%$ in the degree of growth inhibition of $C$. albicans at $10^{6} \mathrm{CFU} / \mathrm{ml}$ of medium [9]. The results of the expected activity at $10^{7} \mathrm{CFU} / \mathrm{ml}$ of medium were similar in direction. The thiotriazoline and decamethoxinum combination was slightly inferior in terms of the antimicrobial and fungicidal effects of chlorhexidine.

\section{Conclusions}

The thiotriazoline and decamethoxinum model mixture exhibits high anti-inflammatory, antimicrobial, fungicidal activity.

The prospect of further research. According to the data shown in the article, it can be argued that this combination based on decamethoxin and titotriazoline shows significant success in the field of use, as a new drug. By inhibiting the effects of decamethoxin toxicity, this opens up new possibilities for this dosage form. The administration of thiotriazolin as an antioxidant expands the therapeutic effect on diseases caused by pathogenic strains and bacteria.

\section{Funding}

The work is part of the part of integrated work of the Department of Pharmaceutical Chemistry of Zaporizhzhia State Medical University and SPA "Pharmatron".

Conflicts of interest: authors have no conflict of interest to declare. Конфлікт інтересів: відсутній.

Information about authors:

Kucherenko L. I., Dr.hab., Professor, Head of the Department of Pharmaceutical Chemistry, Zaporizhzhia State Medical University, Vice-President of SPA "Farmatron", Zaporizhzhia, Ukraine. ORCID ID: 0000-0003-2229-0232

Bielenichev I. F., Dr.hab., Professor, Head of the Department of Pharmacology and Medical Formulation, Zaporizhzhia State Medical University, Ukraine.

ORCID ID: 0000-0003-1273-5314

Chonka O. O., Postgraduate student of the Department of Pharmaceutical Chemistry, Zaporizhzhia State Medical University, Ukraine. ORCID ID: 0000-0002-6793-2668
Moriak Z. B., Associate Professor of the Department of Pharmaceutical Chemistry, Zaporizhzhia State Medical University, Ukraine. ORCID ID: 0000-0001-9416-9517

Portna O. O. Associate Professor of the Department of Pharmaceutical Chemistry, Zaporizhzhia State Medical University, Ukraine. ORCID ID: $\underline{0000-0002-4752-1888}$

Відомості про авторів:

Кучеренко Л. І., д-р фарм. наук, професор, зав. каф. фрармацевтичної хімії, Запорізький державний медичний університет, віцепрезидент НВО «Фарматрон», м. Запоріжжя, Україна.

Бєленічев І. Ф., д-р біол. наук, професор, зав. каф. фрармакології та медичної рецептури, Запорізький державний медичний університет, Україна.

Чонка О. О., очний аспірант, викладач-стажист каф. фрармацевтичної хімії, Запорізький державний медичний університет, Україна. Моряк 3. Б., доцент каф. фрармацевтичної хімії, Запорізький державний медичний університет, Україна.

Портна О. О., доцент каф. фрармацевтичної хімії, Запорізький державний медичний університет, Україна.

Сведения об авторах:

Кучеренко Л. И., д-р фарм. наук, профессор,

зав. каф. фрармацевтической химии, Запорожский государственный медицинский университет, вице-президент НПО «Фарматрон», г. Запорожье, Украина.

Беленичев И. Ф., д-р биол. наук, профессор, зав. каф. фрармакологии и медицинской рецептуры, Запорожский государственный медицинский университет, Украина.

Чонка О. О., дневной аспирант, преподаватель-стажёр каф. фрармацевтической химии, Запорожский государственный медицинский университет, Украина.

Моряк 3. Б., доцент каф. фармацевтической химии, Запорожский государственный медицинский университет, Украина.

Портная Е. А., доцент каф. фармацевтической химии, Запорожский государственный медицинский университет, Украина.

References

[1] Danilevskii, N. F., \& Borisenko, A. V. (2000). Zabolevaniya parodonta [Periodontal disease]. Kiev : Zdorov'e. [in Russian].

[2] Mazur, I., Peredrii, V., \& Dulko, S. (2010). Farmakolohichni zasoby dlia mistsevoho likuvannia tkanyn parodontu [Pharmacological chemicals for the local treatment of periodontal tissues]. Sovremennaya stomatologiya, (5), 47-52. [in Ukrainian].

[3] Borisenko, A. V. (2013). Zabolevaniya parodonta [Periodontal disease]. Kiev: Meditsina. [in Russian].

[4] Petersen, P. E. (2003). The World Oral Health Report 2003: continuous improvement of oral health in the 21 st century - the approach of the WHO Global Oral Health Programme. Community Dentistry and Oral Epidemiology, 31, 3-23. https://doi.org/10.1046/j..2003.com122.x

[5] Mossey, P. A., \& Modell, B. (2012). Epidemiology of Oral Clefts 2012 . An International Perspective. Cleft Lip and Palate: Epidemiology, Aetiology and Treatment, 16, 1-18. https://doi.org/10.59/000337464

[6] Glendor, U. (2009). Aetiology and risk factors related to traumatic dental injuries--a review of the literature. Dental traumatology, 25(1), 19-31. https://doi.org/10./j.1600-9657.2008.00694.x

[7] Petersen, P. E., Bourgeois, D., Ogawa, H., Estupinan-Day, S., \& Ndiaye, C. (2005). The global burden of oral diseases and risks to oral health. Bulletin of the World Health Organization, 83(9), 661-669. https://doi.org//S0042-968620050009000

[8] Gozhaya, I. N. (2012). Risk razvitiya zabolevanii parodonta pri nalichii khronicheskikh sotsial'nykh stressov u klinicheski zdorovykh lits [The risk of developing periodontal disease in the presence of chronic social stress in clinically healthy individuals]. Parodontologiya, (1), 21-25. [in Russian].

[9] Tsepov, L. M., Goleva, N. A., \& Nesterova, M. M. (2010). Khronicheskii generalizovannyi parodontit: ot patogeneza k lecheniyu [Chronic generalized periodontitis: from pathogenesis to treatment]. Dental Yug, (9), 32-34. [in Russian]. 